\title{
Summary: Canada's Food-borne Illness Outbreak Response Protocol
}

\author{
Vik $\mathbf{J}^{1^{*}}$ and Hexemer $\mathbf{A}^{1}$ \\ 1 Outbreak Management Division, Centre for Food-borne, Environmental and Zoonotic Infectious Diseases, Public Health \\ Agency of Canada, Guelph, ON \\ * Corresponding author: jenni.vik@phac-aspc.gc.ca
}

\section{Abstract}

Background: The burden of illness due to food-borne pathogens each year in Canada is significant. Investigations of food-borne illness outbreaks, particularly those with cases in more than one jurisdiction, are complex. Accordingly, efficient outbreak response requires the coordination and collaboration of many investigative partners.

Objective: To highlight the Public Health Agency of Canada's Food-borne IIIness Outbreak Response Protocol (FIORP), the primary guidance document for investigations of multi-jurisdictional food-borne illness outbreaks in Canada.

Approach: The current version of the FIORP was developed in 2010 by the Public Health Agency of Canada following consultation with Health Canada, the Canadian Food Inspection Agency, and provincial and territorial stakeholders.

Results: The FIORP outlines guiding principles and operating procedures to enhance collaboration and coordination among multiple investigative partners in response to multi-jurisdictional food-borne illness outbreaks. It has provided guidance for the conduct of 22 such investigations led by the Public Health Agency of Canada's Centre for Food-borne, Environmental and Zoonotic Infectious Diseases between 2011 and 2013. Furthermore, it has also served as a guide for the development of provincial protocols.

Conclusion: The timely and effective investigation of and response to multi-jurisdictional food-borne illness outbreaks in Canada is facilitated and enhanced by the FIORP.

\section{Introduction}

The causes of food-borne illness are varied and may include a host of viruses, bacteria, parasites and toxins. Food-borne pathogens account for approximately 4 million episodes of illness in Canadians each year (1), ranging from mild illness to significant morbidity with long-term sequelae or death. The economic impact of food-borne illness in Canada is also substantial and has been estimated at almost $\$ 1.1$ billion for every 1 million annual cases of acute bacterial food-borne illness alone (2).

The investigation of and response to food-borne illness outbreaks with cases in more than one province or territory, or in Canada and another country, is a complex undertaking, requiring the involvement of multiple departments from different levels of government. The primary document for guiding the collaborative efforts required in a multi-jurisdictional food-borne illness outbreak investigation in Canada is the Food-borne IIIness Outbreak Response Protocol (FIORP) (3).

Given the high profile of food-borne illness outbreaks in Canada, and the ongoing relevance and central role of the FIORP in such investigations, the present article will provide a summary of the Protocol's main features, 
including its purpose and guiding principles, stakeholder roles and responsibilities, and investigation operating procedures.

\section{Approach}

The FIORP was first developed in 1999 and was subsequently revised in 2006 to incorporate the role of the Public Health Agency of Canada after the Agency's creation in 2004. The current FIORP document was updated in 2010 following a consultative process with federal/provincial/territorial stakeholders, including the Council of Chief Medical Officers of Health and the Federal/Provincial/Territorial Deputy Ministers of Health.

\section{Protocol}

Food safety and public health are areas of shared jurisdiction among all levels of government in Canada. As a result, the identification of and response to multi-jurisdictional food-borne illness outbreaks requires active collaboration among a large number of players. The FIORP applies to enteric outbreaks in Canada when cases are reported in more than one province or territory, or in Canada and another country, and multiple agencies are involved. The scope of the FIORP includes determining the potential existence for a multi-jurisdictional food-borne illness outbreak through to the post-outbreak review process.

The objectives of the FIORP are to enhance collaboration and coordination among partners, establish clear lines of communication, and improve the efficiency and effectiveness of the outbreak response. To meet these objectives, the FIORP delineates the roles and responsibilities of investigative partners (Table 1) and provides detailed operating procedures for coordinating the response to a potential multi-jurisdictional food-borne illness outbreak. While the FIORP serves to guide the collaboration of partners in the identification of and response to such outbreaks, including guidance on notification of partners, communication and information-sharing, it does not provide detailed instructions for the conduct of an outbreak investigation. The FIORP can also be used as a model for provinces and territories to develop their own food-borne illness outbreak response protocols when multiple jurisdictions or organizations within a single province or territory are involved.

Table 1: Roles and responsibilities of investigative partners during a multi-jurisdictional food-borne illness outbreak

\begin{tabular}{l|l|l}
\hline Investigative partner & Role & Responsibility \\
\hline $\begin{array}{l}\text { Local/regional public health } \\
\text { officials }\end{array}$ & $\begin{array}{l}\text { Investigate cases of human enteric } \\
\text { illness. } \\
\text { Conduct inspections and implement } \\
\text { control measures to reduce health } \\
\text { risks related to food. }\end{array}$ & $\begin{array}{l}\text { Report cases of enteric illness and } \\
\text { food safety investigation findings to } \\
\text { provincial/territorial public health } \\
\text { officials. }\end{array}$ \\
\hline $\begin{array}{l}\text { Provincial/territorial public health } \\
\text { officials }\end{array}$ & $\begin{array}{l}\text { Conduct provincial/territorial } \\
\text { surveillance of enteric illnesses. } \\
\text { Validate and coordinate the } \\
\text { exchange of epidemiologic data } \\
\text { between local/regional and federal } \\
\text { public health officials. } \\
\text { Conduct laboratory analyses of } \\
\text { clinical, food and environmental } \\
\text { samples collected in respective } \\
\text { jurisdictions. }\end{array}$ & $\begin{array}{l}\text { Report cases of enteric illness and } \\
\text { results of laboratory analyses to } \\
\text { federal public health officials. }\end{array}$ \\
\hline
\end{tabular}




\begin{tabular}{|c|c|c|}
\hline Investigative partner & Role & Responsibility \\
\hline $\begin{array}{l}\text { Provincial/territorial agriculture } \\
\text { officials }\end{array}$ & $\begin{array}{l}\text { Conduct food safety investigation at } \\
\text { facilities that are not the regulatory } \\
\text { responsibility of the Canadian Food } \\
\text { Inspection Agency. } \\
\text { Implement measures to control the } \\
\text { potential source of enteric illnesses. }\end{array}$ & $\begin{array}{l}\text { Report investigation findings and } \\
\text { actions to investigative partners. }\end{array}$ \\
\hline Public Health Agency of Canada & $\begin{array}{l}\text { Conduct national surveillance of } \\
\text { enteric illnesses. } \\
\text { Conduct centralized analysis of } \\
\text { epidemiologic data. } \\
\text { Assess the weight of epidemiologic } \\
\text { evidence for action. } \\
\text { Conduct laboratory analyses and } \\
\text { provide laboratory reference services } \\
\text { for strain identification and } \\
\text { characterization of clinical, food and } \\
\text { environmental samples. } \\
\text { Lead and coordinate public } \\
\text { communications. }\end{array}$ & $\begin{array}{l}\text { Lead and coordinate the response to } \\
\text { multi-jurisdictional outbreaks. }\end{array}$ \\
\hline Canadian Food Inspection Agency & $\begin{array}{l}\text { Conduct food safety investigation, } \\
\text { including inspection activities. } \\
\text { Coordinate food recalls and other } \\
\text { measures to control the potential } \\
\text { source of illnesses. } \\
\text { Provide laboratory analysis of food } \\
\text { samples. }\end{array}$ & $\begin{array}{l}\text { Report investigation findings and } \\
\text { actions to investigative partners. }\end{array}$ \\
\hline Health Canada & $\begin{array}{l}\text { Conduct a health risk assessment of } \\
\text { the implicated source(s) of illnesses. } \\
\text { Develop health policies and } \\
\text { standards based on investigation } \\
\text { findings, when applicable. }\end{array}$ & $\begin{array}{l}\text { Assign a health risk to the implicated } \\
\text { source(s) of the illnesses. }\end{array}$ \\
\hline
\end{tabular}

A guiding principle of the FIORP is that an Outbreak Investigation Coordinating Committee serves as the main forum for sharing and interpreting information in an outbreak investigation. The Committee comprises representatives designated to act on behalf of the partners from the different departments and levels of government involved in a given outbreak investigation. These representatives may be from the Public Health Agency of Canada, Health Canada, the Canadian Food Inspection Agency, provincial/territorial public health and agricultural departments, or local public health units. Expertise from other agencies, such as those involved in emergency response or the Royal Canadian Mounted Police, is sought as needed. Representation on an Outbreak Investigation Coordinating Committee includes those with expertise in epidemiology, microbiology, food safety and communications.

The main objectives of an Outbreak Investigation Coordinating Committee are to facilitate communication among participating agencies, to serve as a central point to share information from all sources, to discuss outbreak investigation findings, and to achieve consensus on investigation direction and public health action. Any partner in an outbreak situation may request that such a Committee be activated. The Centre for Food-borne, Environmental and Zoonotic Infectious Diseases at the Public Health Agency of Canada is responsible for the coordination of the Outbreak Investigation Coordinating Committee and is considered the lead organization. However, in exceptional circumstances, when a multi-jurisdictional outbreak has occurred predominantly in one province or territory and 
that jurisdiction has already established an investigation team, upon the agreement of all Outbreak Investigation Coordinating Committee representatives that province or territory may assume the lead of the Committee.

Each federal/provincial/territorial partner that could be engaged in a nationally led Outbreak Investigation Coordinating Committee has an appointed primary designated representative, known as a FIORP duty officer. Upon activation of the Committee, the Committee lead is responsible for contacting all FIORP duty officers to inform them that the Committee has been established and to ensure that they receive summaries of its activities and actions. FIORP duty officers, in turn, are responsible for the participation of their jurisdiction in the Committee, as required, and notifying and providing regular updates to senior officials within their organization.

Another guiding principle central to the FIORP is that laboratory, epidemiologic or food safety evidence is used to establish the association between illness and a particular food as the source of an outbreak. The Public Health Agency of Canada, as the Outbreak Investigation Coordinating Committee lead, is responsible for coordinating the epidemiologic investigations of food-borne illness outbreaks, including the overall collation and analyses of epidemiologic data, in collaboration with the affected partners. Food safety investigations are undertaken by the Canadian Food Inspection Agency or the appropriate regulatory officials within the affected jurisdiction. Each partner is responsible for conducting appropriate laboratory testing of clinical and food samples, and sharing the results for discussion with the Committee.

Although the Public Health Agency of Canada leads and coordinates public communications, each Outbreak Investigation Coordinating Committee partner also has responsibility for public communications within its respective jurisdiction. Communications staff and content experts in the Committee work together to develop products to provide updates to the public, the media and other stakeholders, as required, according to risk communications principles. Communication activities are coordinated among Committee partners to achieve consistent and complementary messaging across involved jurisdictions.

Health Canada is responsible for carrying out a health risk assessment of a food that is suspected of being the source of an outbreak. Epidemiologic, microbiologic and food safety data are considered in the assessment, which in turn determines the level of risk posed by the suspected source/implicated food. Health risk assessment decisions are shared with the Outbreak Investigation Coordinating Committee and are used to inform public health action. Public health and food safety actions to address the source of a food-borne illness outbreak may include issuing a recall, detaining a product, disposing of food, public communication regarding prevention and control measures, case and contact management, and prophylaxis (e.g. vaccination for hepatitis A contacts), as well as the review and enhancement of industry procedures and requirements, and the updating and/or development of new government policies, standards or guidelines.

A new feature of the 2010 FIORP was the addition of the option for any partner involved in an outbreak response to request a post-outbreak review. Such reviews, generally chaired by the Outbreak Investigation Coordinating Committee lead, provide an opportunity for partners to examine what worked well and what could have been improved in a particular investigation. Committee partners may identify measures to prevent recurrence, such as new or revised policies or standards; assess the need for further scientific studies; develop improved practices for future investigations; and recommend improvements or adjustments to the FIORP.

Since being revised in 2010, the FIORP has served as the guiding protocol for 22 Outbreak Investigation Coordinating Committees led by the Centre for Food-borne, Environmental and Zoonotic Infectious Diseases, Public Health Agency of Canada, between 2011 and 2013. These outbreak investigations have involved both domestic and international partners, and implicated pathogens have included E. coli, Salmonella, Listeria, Cyclospora and hepatitis A. The FIORP is currently undergoing review, and a revised version will be developed. The Public Health Agency of Canada, as the custodian of the FIORP, will oversee this process through collaborative engagement of key partners and incorporation of recommendations received through post-outbreak reviews. 


\section{Conclusion}

The FIORP plays an essential role in the effective investigation of and response to multi-jurisdictional food-borne illness outbreaks in Canada. Scheduled review of its provisions ensures that it can adapt to changing realities and provides a means to incorporate post-outbreak recommendations and lessons learned.

\section{Conflict of interest}

There are no conflicts of interest to declare.

\section{References}

(1) Thomas MK, Murray R, Flockhart L, Pintar K, Pollari F, Fazil A, et al. Estimates of the burden of food-borne illness in Canada for 30 specified pathogens and unspecified agents, circa 2006. Foodborne Pathog Dis 2013 Jul;10(7):639-48.

(2) Todd E. Costs of acute bacterial food-borne disease in Canada and the United States. Int J Food Microbiol 1989;9(4):313-26.

(3) Public Health Agency of Canada. Canada's food-borne illness outbreak response protocol (FIORP) 2010: to guide a multi-jurisdictional response. Government of Canada, 2012. http://www.phacaspc.gc.ca/zoono/fiorp-mitioa/index-eng.php 